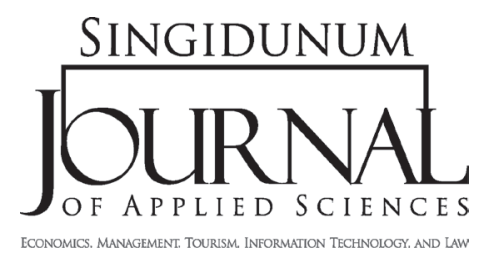

SINGIDUNUM JOURNAL 2012, 9 (1): 16-28

ISSN 2217-8090

UDK 005.94:005.346

Original paper/Originalni naučni rad

\title{
THE ROLE OF KNOWLEDGE MANAGEMENT IN BUILDING CLIENT RELATIONSHIPS ${ }^{1}$
}

\author{
Jelena Đorđević Boljanović1, ${ }^{1,}$, Jelena Stanković ${ }^{1}$ \\ ${ }^{1}$ Singidunum University, Department for Business Economics, \\ 32 Danijelova Street, Belgrade, Serbia
}

\begin{abstract}
:
Knowlegde Management represents an interdisciplinary business model which focuses upon knowledge generation and its exchange within an organisation. Employees hold the key role in the processes of knowledge generation and its distribution, and their satisfaction forms the paradigm of successful knowledge management execution.

Over last decade Customer Relation Management (CRM) proved to be a concept indispensable for achieving business success with companies operating in a global market. Its essence is based upon establishing and maintaining long term client relationships which aim to create value for both the client and the organisation.

Like any other kind of relationship, organisation - client relationships experience alterations over the "client relationship life cycle". Organisation itself causes "return on relationships" to develop during this process. Directly aimed at their mutual goal - client satisfaction, CRM and knowledge management take effect in a synergetic form through an integrated concept of Customer i.e. Client Knowledge Management (CKM). Multidimensionality of contemporary business practice requires linking competencies of experts in different core business fields, especially in knowledge sharing, communication and developing partner relationship within business practice.
\end{abstract}

\author{
Key words: \\ customer relationship \\ management (CRM), \\ partner relations, \\ client relationship life cycle, \\ customer knowledge management \\ (CKM), \\ linking competencies.
}

\section{INTRODUCTION}

As the intellectual component in products and services gains more and more importance, developing knowledge management within an organisation wins greater priority. All present-day companies compete in knowledge, but unless applied and accessible to all who might need it at any time given, the knowledge existence within a company becomes useless. In this sense, knowledge management implies aquiring collective knowledge with the aim of achieving a company's business goals. Basically, the role of knowledge management is to guarantee that people can access all knowledge they need, where they need it and when they need it, i.e. actual knowledge at the right place, in the right time.

1 This paper is a part of the research project Improving the competitiveness of Serbia in the process of accession to the European Union, No. 47028 for the period 2011 - 2014, supported by the Ministry of Education and Science of the Republic of Serbia. 


\section{PREREQUISITES FOR SUCCESSFUL APPLICATION OF KNOWLEDGE MANAGEMENT}

Although there is no universal definition of knowledge management, a conclusion can be derived from analysis of definitions of this concept occurring in the literature, that every knowledge management definition implies exploitation of knowledge accessible from external sources, its implementation and storage in business processes, products and services, its representation in databases and documents, promotion of knowledge increase through organizational culture and employee motivation, transmitting and applying knowledge throughout organization, as well as estimating benefits resulting from knowledge use and its implementation into the organization basis. The most general approach to this concept is to view knowledge management as a process representing unity of the three components (Macintosh, 1995): people, processes and technology and which goes through the following phases: knowledge creation, knowledge capture, knowledge storing, knowledge sharing and knowledge application, thus forming its life cycle.

As a strategic approach to knowledge management, which considers the unity of technology and human factors as the foundation for survival in a variable environment, the definition given by $\mathrm{Y}$. Malhotra (1997) stands out by defining knowledge management as follows: "Knowledge management refers to the critical issues of organizational adaptation, survival and competence against discontinuous environmental change. Essentially it embodies organizational processes that seek synergistic combination of data and information processing capacity of information technologies, and the creative and innovative capacity of human beings." It is the concept representing collective knowledge of an organization with the ultimate goal to apply this knowledge efficiently to the decision making situations. Concisely, knowledge management is the process through which organizations generate value from their intellectual and knowledge-based assets (Santosus and Surmacz, 2001).

To gain insight into successful application of knowledge management concept, it is crucial to study the factors which determine the level of success and competitiveness of an organization. The claim of this program, requiring various employee competencies, is supported by virtually unified au- thors' opinion (Mertins et al., 2001). Subsequently, corporate culture, human resources management, leadership, information technologies and control are key factors which determine knowledge management program success.

Instances of numerous business activities and fields prove that free knowledge flow and a successful knowledge management program are the preconditions of successiful business practice. For example, particularly in the field of trading and services business orientation is based upon sense-andrespond (your clients' needs) philosophy (Kotler, 2003). The mission of present-day organizations no longer consists of finding the right consumer for the created products and services, but comprises creating the right product and service offer for prospects and the existing clients. A company's customer centered business practice covers all business activities involved in the fields of marketing and product or service distribution. This would cause lowering the costs of attracting clients in the long run and would consequently build customer loyalty to the organisation. The precondition for such business orientation is certainly availability and accesibility of knowledge in all business practice segments within this field, and it will be disscussed in further parts of this paper.

\section{COSTUMER RELATIONSHIP MANAGEMENT AND KNOWLEDGE CREATION}

The concept of Customer Relationship Management (CRM) includes directing a company's marketing activities towards establishing, forming and maintaining good long term business relations with the selected consumer segments, and it is based upon making use of electronic technology. Adrian Payne (2006) views CRM as an approach to modern business practice aimed at creating, developing and strengthening business relationships of a company with carefully selected consumer segments in order to optimize value for both the consumers and business profitability, and generally to maximize value for all company stakeholders. Parvatiyar and Sheth's (2001) view of CRM concept is defined as a comprehensive strategy and process aimed to attracting, maintaining and enhancing partner relationships with selected consumer segments, with the final goal of creating superior value both for customers and the company itself. 
One of the key superior values for an organization is the knowledge it possesses, and its ability to apply this knowledge to its business decision making processes. Knowledge management process has five distinct stages, namely: creation, acquiring, storage, sharing, and application of knowledge (ĐorđevićBoljanović, 2009). The first step is knowledge creation. It represents the initial link which enables an organization to start building and applying its knowledge, and which forms a knowledge pool to be used in processes that manage corporate marketing activities.

The new economy implies a shift from mere data collection-based marketing and creation of consumer databases towards CRM, as a process of modifying consumer behavior over time, thus enabling the organization to learn from every interaction with customers and to adapt to their behavior and habits. The flow of communication with consumers consists of various episodes that vary in content, frequency, duration, and the impact they have on business relationships. Considering the significance of an episode for consumer's assessment of relations with retailer, episodes can be classified as routine and critical ones.

Routine episodes are situations which haven't led to significant changes nor improvements in relations among retailers and consumers, either positive or negative. In retail communication, they can grow into critical, even if an agreement with the retailer is not reached. Critical episodes, from the consumer's standpoint, have great significance for future communication and business relationships with the retailer. These are the interactions among customers and employees within an organization, and may be either highly satisfactory or extremely unsatisfactory (Bitner et al., 1990).

During a retail communication episode, the customer experiences one or more interactions with the retailer while they are being served. With consumers, these interactions can create cognitive equilibrium (feeling of satisfaction) or disequilibrium (feeling of dissatisfaction). In other words, while being served, consumers experience an impression of satisfaction or dissatisfaction, which is the key to creating critical episodes as a factor of changes in business practice and communication.

In the process of gathering information and creating knowledge about building the relationships and the consumer satisfaction degree, it is of the utmost importance for a commercial or service business to establish whether or not there were changes in communication, and whether these changes are positive or negative in terms of future business relations. A retail market research, conducted in Serbia among other things, has dealt with collection of knowledge on consumer-retailer relationship (Stanković, 2009). The consumer sample has consisted of 503 adults, into two age groups: (a) younger, aged 18 - 25, and (b) older than 25 . The sample of retail businesses has featured their representatives present on the local market who communicate with consumers directly, either traditionally or electronically.

According to this study, after the purchase process, a significant majority of consumers, up to $66.2 \%$, experiences a certain feeling (satisfaction or dissatisfaction) about the purchase made (Stanković, 2009). Consumers are therefore indifferent to the completed purchases and collaboration with their retailers.

A series of interactions that build an episode create a service chain. It can be analyzed both from the consumer's and the company's standpoint.

The other end of this communication chain is the organization which uses information gathered during a series of interactions to improve the relations established with its clients. At the same time, it also represents a further concretization of the stance on the bond between the concepts of knowledge management and customer relations management. An interesting classification of knowledge which plays a major role in the organization - clients interaction can be used to support this stance: the professors of St. Gallen University (Dous et al., 2005) have classified knowledge into: the knowledge "for", the knowledge "from" and the knowledge "about" customers.

The first type of knowledge, aimed at the customer's support during the purchase process, flowing directly from the company to its customers, represents a prerequisite for successful business practice. The knowledge "for" client comprises information on the products (services), the market and the suppliers. As for the second type of knowledge, the one "from" customers, it is of crucial importance to implement it into company business practice in order to promote product and service innovation, spread of new ideas, as well as continuous improvement of its products and services. Collection and analysis of the knowledge "about" customers certainly represents the oldest type of knowledge management activities in the field of CRM. In addition to basic data on customers and their past purchases or services used, this type of 
knowledge includes current consumer demands and needs, their future aspirations, activities, and financial capabilities.

\section{KNOWLEDGE ABOUT CUSTOMERS AS A SOURCE OF COMPETENCE}

The knowledge management plays an important role in the concept of CRM through the following three levels (MacStravic, 2004):

- The knowledge management within Customer Interaction Management (CIM) represents the knowledge which the company acquires in order to make the sales, marketing and customer service more effective and efficient, as the ultimate goal of CIM. This involves training and enabling all individuals and systems to access and use knowledge in order to identify the reasons out of which a customer demands specific goods or services, the criteria for selecting specific brands and providers, the channels for seeking or receiving the necessary information. The emphasis is on knowledge about clients in general.

- The knowledge management within Customer Experience Management (CEM) refers not only to customers' expectations, but also considering the elements that may cause their dissatisfaction, which has already been discussed. All this requires a separate evaluation of customers significant for the company, and of marginal customers who are not that profitable for its business. This type of knowledge can be used for particular customization, purchase frequency increase and value creation for the company. The existing knowledge on what the customers like and dislike, and the knowledge about their current and potential interest for some other products or services that the company provides, form the basis for the application of the knowledge management concept in CEM.

- The knowledge management within Customer Success Management (CSM) focuses upon continuous relations and the impact on potential customers, trying to establish how these relations and experience in transactions affect them and how to exploit this effect for the mutual benefit of both the buyer and the organization. Here we primarily think of the usefulness of knowledge which can be directly enhanced by a successful knowledge management program,
Boljanović J., Stanković J. § The role of knowledge management

with the aim of motivating customers. Therefore, it is of the utmost importance for an organization to acquire knowledge on what kind of impact the customers expect them to carry out, why the customers are loyal to the existing relationship with a particular organization etc.

The parallel implementation of knowledge management and Customer Relationship Management concepts in the companies belonging to both public and private sectors of the economy, has led to the development of the Customer Knowledge Management (CKM) concept (Gibbert et al., 2002). Amrit Tiwana (2001) also terms this concept as "knowledge - enable customer relationship management", thus implying the ability to manage customers' knowledge in order to establish standards of forming value and to share knowledge, with the ultimate goal of strengthening relations and enhancing communication and business practice efficiency. An organization that succeeds in integration of its knowledge into the minds of its employees and its clients (human capital), into the current opportunities and capabilities (structural capital) and into connections and relationships (relationship capital), is on the right way to become a leader. More concisely, an organization must learn to alter their behaviour patterns exclusively in the direction of what they know about their clients (Tiwana, 2001). The memorable quote "if only we knew what we know" originally by Lew Platt, a former HewlettPackard CEO ("If only HP knew what HP knows, we would be three times as profitable."), in fact, expresses the very essence of the knowledge management concept. It could be, in a sense of observing the links between the Knowledge Management and Client Relationship Management concepts, changed into "if only we knew what our customers know." In fact, companies have become aware of the fact that the knowledge, necessary to create and sustain competitive advantage, must also include the knowledge a company owns about its customers (but also about those who are not their customers). Or, as P. Drucker (Draker, 2002) put it: The present-day customer has information ... The one who has information has power. Power therefore shifts towards the customer, be it another company or end user. This further implies the need to strengthen the bonds between the Customer Relationship Management and Knowledge Management concepts, resulting more frequent emphasis on the connection between the two. 


\begin{tabular}{|c|c|c|}
\hline Strategy & \multirow{8}{*}{ 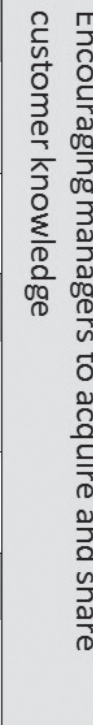 } & \\
\hline $\begin{array}{l}\text { Perceiving customer knowledge as a valuable source } \\
\text { for product innovation and process improvement }\end{array}$ & & \\
\hline & & 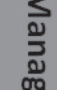 \\
\hline Processes & & 㫕 \\
\hline $\begin{array}{l}\text { Classification of knowledge management activities at } \\
\text { the same level as the CRM processes }\end{array}$ & & $\stackrel{\vec{n}}{\stackrel{\vec{n}}{\overrightarrow{0}}}$ \\
\hline & & 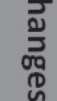 \\
\hline Systems & & \\
\hline $\begin{array}{l}\text { Creation of knowledge repositories throughout the } \\
\text { organization }\end{array}$ & & \\
\hline
\end{tabular}

Figure 1: A conceptual framework for knowledge-based CRM. Source: Dous et al. (2005)

Figure 1 features the conceptual framework of the knowledge flow in an organization, which is a prerequisite for successful implementation of CRM, and this is a precondition of implementation of the CKM concept.

As the figure shows, the key aspects of studying knowledge flow within an organization, essential for the implementation of the CKM concept, are the strategy, processes, systems and change management. The strategy implies perceiving customer knowledge as a valuable source for product innovation and process improvement, meaning that management needs to view its clients not as a burden but as a valuable source of knowledge. The processes imply that the optimal way to manage knowledge is to implement it into employees' regular daily work activities. The systems imply the creation of knowledge repositories within an organization, which are necessary for overcoming the limits and business units separation issue. The change management includes encouraging organization managers to acquire and share their knowledge about clients.

Starting from the strategic framework of applying the CRM concept within organizations (Knox et al., 2003), it is important to put emphasis on the bond between the knowledge creation process and the marketing strategies conducted with the aim to establish good long-term relationships:

- The strategy of attracting and acquiring new customers (Customer Acquisition) represents the implementation of numerous communication and business activities, intended to attract new customers and convince them to make their first purchase with that particular company. It is implemented through a series of offline activities (product and service promotions, innovative ways of communication, direct purchase incentives) and online activities (website, online communication and sharing). It can be said that the implementation of this marketing strategy particularly contributes to the organizational level of learning.

- The strategy of customer retention represents implementation of activities and techniques with the purpose of maintaining business relationships with customers (personalization, mass customization, good purchase deals, creating and activating extranet, as well as creating e-mail groups, forums and online chats).

- The strategy of directing the purchasing trends of consumers and deepening the communicational-business relationships with the most profitable customers (customer extension) represents establishing a deeper and superior quality communication with the most profitable customer segments aimed to increase the long-term, so called lifetime customer value. The implementation of this marketing strategy particularly contributes to the individual level of learning, as the organization strives to es- 
tablish the best possible communication with its premium consumers, even at the individual level.

These strategies require a continuous research to be conducted, the collection of information and the creation of knowledge to be at disposal of the organization's employees, and to be used by managers to make decisions necessary to direct their future cooperation with customers.

The results of a research, conducted on a sample of retailers and consumers in Serbia, confirm that understanding the customer needs and keeping them informed represent a valuable source for innovation in business processes. In fact, the research has shown that there is a sound basis for the claim that an absence of information on a traditional offline retailer leads to the domestic consumers' decision not to be engaged in electronic trade with such retailer (Stanković, 2009). Interestingly, 23.7\% of research participants could not answer this question, suggesting the possibility that emergence of e-companies the consumers know almost nothing about, would lead to numerous difficulties with engaging consumers in electronic trading. It can be assumed that those would primarily be difficulties caused by impossibility of face to face contact with sales staff, the lack of nonverbal communication and body language, as well as other factors that effect building of a trustworthy retailer-consumer relationship, which requires further research. The study concluded that e-retail represents an unknown concept for a large number of consumers, and therefore a novelty in performing purchase activities, establishing communication and relationships with retailers. The "culprit" for this is the lack of information about the retailer, the lack of communication, and the lack in creating knowledge about costumer's needs and requirements. Not being informed about innovations in business practice negatively affects a customer's decision to engage in retailer's new business activities, such as the area of e-business.

The implementation of the Customer Knowledge Management concept (CKM) is of a particular importance when the following characteristics of business relationships are considered (Peppers and Rogers, 2004):

- Reciprocity - Every human relationship is bi-directional. To consider a set up state of business affairs as a relationship, it is essential that both sides participate in establishing it and be aware of the existence of these relations.
Boljanović J., Stanković J. ^ The role of knowledge management

- Interaction - The two sides interact when they exchange information about themselves, and when this exchange becomes a driving force for building their mutual relations. This further implies their mutual interest in building business relationships.

- Iteration - The two sides participating in an exchange is in interaction that takes place over time, which builds a history of their interaction. In time, this history gains a certain context which produces an ever increasing efficiency in future interactions of these participants. Each subsequent interaction is the next iteration, the next step based on all the previous iterations. A series of performed iterations indicates the frequency of retailercostumer interactions, and the quality of their existing relationship. In other words, the more you interact with a person, the easier it will be to understand each other during every subsequent interaction, and to predict their thought pattern.

- Developing mutual benefit - One of the main driving forces of building retailer-consumer relationships is the development of mutual benefit for both parties in the exchange. Due to the aforementioned context of exchange development, and benefits gained and expected, inherent to exchange, it is of an interest to both sides not to make mistakes and to recover rapidly and efficiently from mistakes that still may occur. This happens because both parties expect that the future value, gained in exchange, will exceed costs of investing in that business relationship.

- Changes in behavior - What influences creation of mutual benefit for both parties in the exchange is not just the context, which represents the history of business interactions over time, but also the fact that current and future business activities of both sides reflect that context of trade and their mutual business relations. Business activities evolve over time, as well as the terms of exchange and people themselves including their behavior.

- Uniqueness - Every relationship is different, specific and unique. Companies intending to build good relationships with their customers must be aware of the uniqueness of their needs and demands, and adapt their behavior and communication style to specific characteristics of individual costumers. 
- Trust - The ultimate request, but also the result of any successful relationship with a tendency to develop further, is trust. If a consumer develops a business relationship with a company, they actually intend to develop trust in that company's work, that is to believe that it will operate with the costumer's best interest in mind. Trust is the feeling which makes foundation to development of any relationship, including a business relationship and which determines its future.

The aforementioned characteristics of building business relationships among companies and their customers and clients indicate their complexity, and also their susceptibility to changes. The complexity of established relations and the delicacy of building consumers' trust render the need to learn and analyze their behaviour, needs and shopping habits, as well as their attitudes towards the company after product or service consumption. Therefore, getting familiar with the business situations, studying the factors that have led to their formation, and especially following trends, observing and listening to customer behavior on the market - all of the factors enable companies to deal with emerging potential changes, as well as to reduce the risk of negative effects of future changes.

\section{MARKETING CONCEPTS BASED ON KNOWLEDGE}

Knowledge creation and management are crucial for implementation of some key marketing concepts, the most current of which are Involvement Marketing and Customer Information Management (West, 2000). Consumer Involvement Theory (CIT) implies understanding psychology and behavior of the targeted customer segments, and represents a genuine application of the CKM concept in practice. Consumer behavior provides a retailer with knowledge necessary to create new ideas, approaches and strategies of marketing communication. In this respect, it is crucial to consider the two dimensions of the mentioned concept (McNamara, 2011):

1. Involvement - refers to the time, energy, thought processes, money and other resources that people use in relations with an organization;

2. Rationality / emotionality in decision making (rational / emotional) - represents a scale used to measure ratio $v s$. impulsiveness, desire $v s$. logic, passion. $v s$. wisdom in building the mentioned relationships.
In a study of the telecommunications and health care sector in the U.S., the authors Varki and Wong (2003) came to the following conclusion - the more clients are involved in the exchange process, the greater interest they show in building relationships with service providers, in equality within the exchange and also in active participation in solving problems. Activating the role of costumers with a high degree of involvement in problem solving processes provides the greatest possibilities of building long-term relationships (Varki and Wong, 2003).

Inclusion of consumers in knowledge creation for an organization creates a number of advantages. Firstly, the organization acquires timely and current information about its customers, which is a direct parameter of business quality. Secondly, clients are interested in providing information about themselves, since it directly influences knowledge creation, and thus creation of custom has made an offer, which, in the long run, represents the parameter of trust in the organization. Thirdly, client involvement in the creation of knowledge about themselves is another very significant and valuable long term factor in building partnerships on the market.

At this point, it is interesting to show some data obtained at the retail market of Serbia (Stanković, 2009). Specifically, the results show that a statistically significant majority of consumers feel they represent active participants in the retail business. However, on the other hand, the research has shown the following:

- Consumers in the local domestic market do not feel that retailers really care about them and their needs. This could, in other words, represent a problem and reduce the quality of building customer relationships in the long run.

- There is no sufficient foundation to claim that retailers are concerned enough for individual customer needs and demands nor do the consumers feel that way.

Such results may suggest that domestic retail market doesn't implement so-called planned approach to change management and direction of retail-customer relationships, nor do customers and consumers actively participate in the long-term exchange processes.

The concept of Management of Information Exchange with Customers enables online and offline knowledge collecting, which will be significant for efficient building of good business relationships and 
better customer service. In this sense, the so-called information-intensive strategies play a major role, because they contain the information that needs to be continuously monitored and updated by organizations (Glazer, 2004):

- Customer features (demographic and psychographic data);

- Customer reactions to the company decisions (data on customer preferences, customer behavior and their reaction to the company activities);

- Purchase history (data on the products and services bought and used by costumers; data on revenue, costs and the profits pertaining to the purchase made).

The aforementioned results lead to the conclusion that practical implementation of these marketing concepts effects the construction of six key CKM dimensions (Gordon, 1998):

- Creating new value for customers;

- Identifying the active role of clients in exchange and value creation;

- Designing and establishing business processes, communications, technology and people as indispensable technical support in value creation for customers;

- Establishing cooperation between organizations and their clients;

- Recognizing the value of long-term customer and consumer purchase (so-called customer lifetime value);

- Researching ways to build a chain of business relations within the organization itself, as well as business relationships among the organization and its stakeholders, including suppliers, distribution channels, exchange intermediaries and stakeholders.

Having considered different aspects of the application of knowledge-based marketing concepts, a conclusion can be made that the benefit of these is great if one insists on a multi-dimensional approach to this issue.

\section{MONITORING CUSTOMER RELATIONS LIFE CYCLE AS A FACTOR OF COMPETENCE}

The quality of the concept of modern business is monitored by measuring the profitability of clients and organizations. The research of partnerships among clients and organizations, Gummesson (1999) has observed the formation of so-called "profit chains" or "customer relationship life-cycle". This implies the customer and client value creation process, presented through the stages of relationship management leading to creation of an organization's profit. Storbacka terms this process a "return to business relationship", indicating that the established relationships bring significant benefits to both sides. Profit represents an important benefit for an organization, while consumers and clients find pleasure in the purchase which has been made and having their requests met.

Figure 2 shows the process of making profitability. This includes the processes of profitability development within an organization which form the basis for building business relationships with environment. Raising the quality of internal operations leads to creation of employee satisfaction and motivation in the organization. Raising the quality of their operations leads to a better customer service.

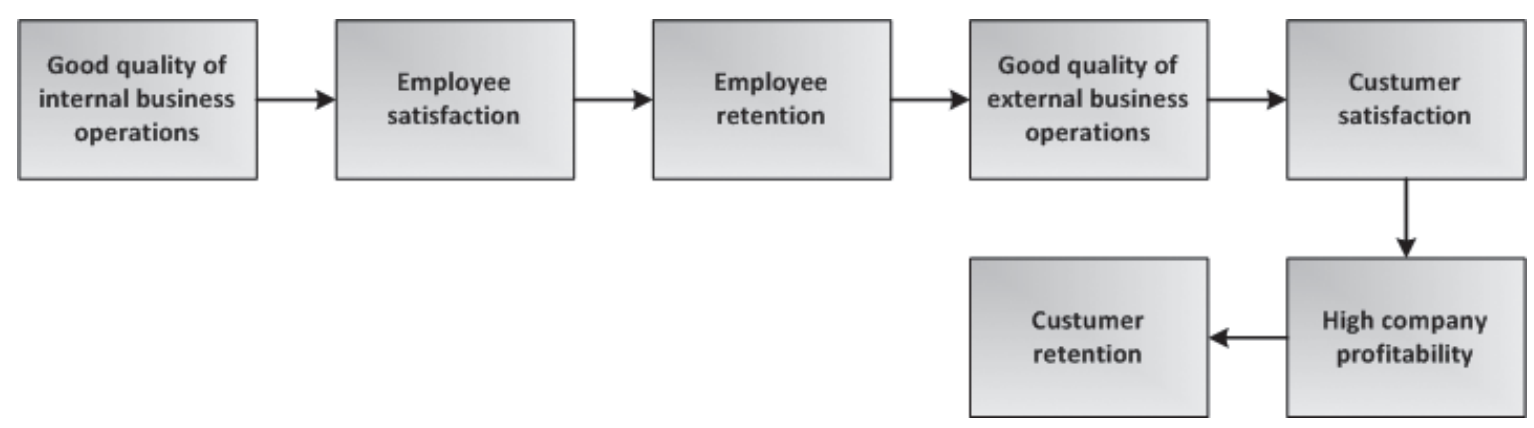

Figure 2: Return on business relationships.

Source: Egan (2004) 
This further leads to customer satisfaction, retention and building customer profitability, but also to creation of the organization profitability. Prerequisite for the creation of return on business relationships is reflected in the quality of communication among employees and in the possibilities and ways of motivating employees to enhance their knowledge. Business communication has to be conducted and monitored within three levels: in organizations themselves, with consumers or clients and among organizations. (Dobrijević, 2010). Clear communication, both verbal and nonverbal, internal communication in an organization as well as the communication with clients and customers, represents an important factor in building employee satisfaction, and consumer trust in their retailers. Among other factors that influence corporate culture, the factor of quality of communication and information flow is one the most powerful (Nikolić and Terek, 2011).

The aforementioned study has found that clear communication is an important factor in building customer trust towards the retailer (Stanković, 2009). Most customers and retailers have evaluated the factor of communication with the sales staff (clear verbal communication, balanced verbal and nonverbal retailer messages, timely information and the like) as an important and/or very important for building trust. Diverse knowledge about customers has a versatile use value for an organization, so identifying high-quality and useful knowledge is a key factor in customer value creation.

Establishing and developing relationships based on learning (Learning Relationship) depend on numerous factors, both those that encourage the development of this process making it a source of organization competence, and those that affect it negatively and diminish it.

As displayed in Figure 3, the established business relationships evolve through the following five stages (Peppers and Rogers, 2004):

I. Awareness of potential trade partners phase In this first stage, potential participants in the trade become aware of the possibility of exchange and, in this sense, establish business relations. However, there still isn't any exchange between them.

II. Research Phase - This is a "trial period" for establishing trade participants relations. Communication is established among them while necessary information are being transmitted, including information on costumer demands, priorities, needs and desires. This phase is a very delicate one, because if one of the involved parties shows insufficient desire, indifference or reserve toward the other party, the development of business relationships could be very quickly and easily disrupted.

III. Expansion phase - This stage takes place if the retail trade participants successfully "overcame" the previous stage, meaning both the retailer and the customer were convinced of the suitability and importance of their trading partners. This enables the strengthening of mutual relations, the interdependence of trading partners, and their willingness to take risks in business operations. A research on Serbian retail market has showed that domestic consumers feel that they represent active participants in the exchange. Namely, the question "Do you feel that, as a buyer (consumer), you represent an

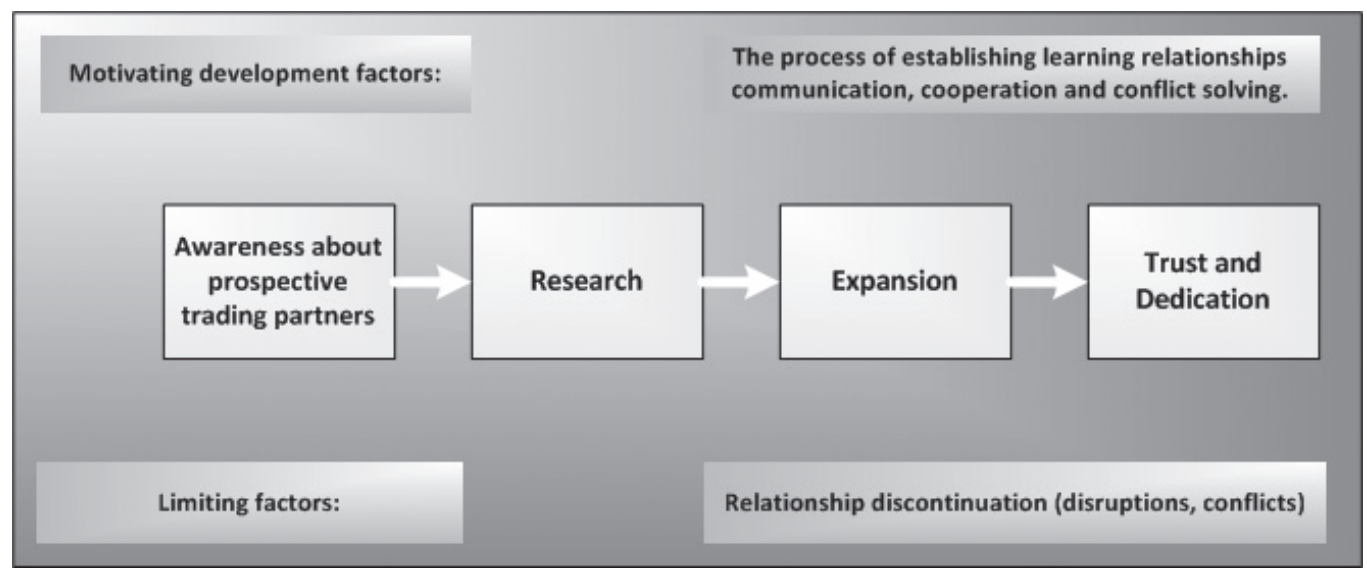

Figure 3: The process of establishing learning relationships.

Source: Peppers and Rogers (2004) 
active participant in the purchase?" was positively answered by $64.2 \%$ of customers ( 323 respondents), which is a statistically significant majority of respondents, while $20.4 \%$ of customers (101 respondents) provided a negative answer. On the other hand, surveyed retailers were asked the question "Does your company strive to actively involve customers in gathering information related to: customer needs, changes in product ranges and services, the atmosphere and arrangement in retail stores, web site design etc.? ". $76.0 \%$ (38 respondents) of the total number of respondents answered with a "yes", while $20.0 \%$ of retailers (10 respondents) answered negatively. A statistically significant majority of retailers on the domestic market aims to actively involve their consumers in the process of gathering information about their needs, as well as other elements of the retail trade (changes in product ranges and services, the atmosphere and arrangement in retail stores, web site design etc.) (Stanković, 2009).

IV. Phase of trust and commitment - At this stage, the partners, having established a business relationship, reached a certain satisfaction level with it, and are aware of the benefits this relationship brings. Consequently, the parties in the exchange begin to develop commitment to the established relationships and the feeling of trust is created. Therefore, both partners are much less prone to consider alternative business relationships with other potential trading partners. Partners are interested in a consistent investment into their business relationship, and into its long-term orientation. At this stage, consumers gain a sense that they represent active participants in the exchange.

V. Disruption (conflict) phase - Disorders are always possible and potentially present. The stage of disorder occurs when one of the parties estimates that the costs of further investment into a business relationship will exceed the benefits that party gains from this business relationship. This phase can occur during any development stage of business relations.

Through the entire evolution process of learning relationships, the factors which encourage the development of these relations occur. One of these factors is communication, expressed through formal and informal communication styles of trading partners, as well as through verbal and nonverbal forms of communication. Electronic communication has enabled the establishment of direct, personal communication, which can additionally effect the development of consumer trust in their retailers. Cooperation is an important motivating factor, because it involves both trading partners, it deepens their communication and creates a sense of relationship permanence, equality and reciprocity in business. While the factor of conflicts is negative for the business relations development, the conflict resolution factor encourages this development. Reaching a mutually acceptable compromise, without having to implement formal procedures, especially impacts the development of trust among the exchange partners, as well as commitment to developing their business relationships.

Managing the process of establishing learning relationships depends on the retailer's ability to perform filtering of information received from its customers, to use them and manage the information useful for their future cooperation. Consumers are, on the other hand, very precise in their expectations of retailers. They simply expect to get what they want - when they want it, where they want it, and in the way they want it. Modern technology makes it possible to respond to these consumer desires with the right product at the right time, on the right place and in the right way. Communication technologies and database management technology enable retail companies to collect large amounts of data on individual customer needs and demands, and also enable their use in customizing products and services to meet specific customer needs and demands. (Pine et al., 1995).

The introduction of e-business leads to abandonment of the outdated "product-centric" business orientation, based on the product ranges, and to its transition to a "customer-centric" business orientation based on customer needs. Modern business enterprises are also called "customer-strategy enterprise" (Peppers and Rogers, 2004), referring to their partnership with the clients as the focus of the business.

Peppers and Rogers (2004) suggest that developing partnerships between organizations and their clients guarantees stability of the trade between them. If customers choose to engage in exchanges with a competitive organization, they need to spend some time and energy, often very much time and energy, to get to know a new organization and provide it with the same information and knowledge their former partners have already acquired about them. This decision leads to the so-called switching cost, 
which occurs when a consumer establishes trading relationships with another organization. Therefore, developing a quality relationship with the existing trade partner and developing loyalty to it represents a more profitable option for a consumer.

Partnerships are an integral part of the process of generating knowledge about the partner in the exchange - the so-called "knowledge-generating process" (Håkansson and Johanson, 2001). These are built on the basis of knowledge about the trading participants, and imply the organization's obligation to adapt its offer to customer needs when customers provide information about themselves (Peppers and Rogers, 2000). With each subsequent interaction, their relationship gets better and better, and also "smarter and smarter" (Egan, 2004) in terms of expanding knowledge about the client, in terms of the organization's ability to predict future customer needs. Due to all this, learning relationships as a form of partnership represent important and powerful means of creating competitive advantage of organizations. (Selnes and Sallis, 2003). In this way, an organization learns about the characteristics, needs and desires of each individual customer through conducting business transactions and communication interactions. On the other hand, a consumer learns about the characteristics of their partner organization through the processes of product purchase and using its services. We can conclude that the benefits of these partnerships are the following (Peppers and Rogers, 2004):

1. From each new trading experience, and through any feedback received from their partner organizations, the client himself learns more and more about their own preferences. Thus the client becomes more capable, more efficient and effective in the purchase processes, as well as in managing other aspects of their personal and business life.

2. From each new interaction and each subsequent feedback received from their clients, the organization learns about their own strengths and weaknesses, advantages and disadvantages. Consequently, it becomes able to manage the marketing, communicational and other aspects of their business more efficiently and effectively.

This leads to the conclusion that in the era of business interactivity, in which clients participate actively in business and where it is possible to do business with each individual client, one of the critical factors of business success is establishing quality relationships with a particular group of the most profitable customers.

\section{CONCLUSIONS}

The previously mentioned shift of market economy towards a new, knowledge economy, also requires changes in the approach to marketing. Customers no longer wish to be treated uniformly, but individually. Therefore, the new economy implies a shift from mere data collection and customer database creation based marketing, to an actual Customer Relations Management (CRM) - a process that modifies a consumer's behaviour over time enabling the organization to learn from every interaction with its customers and to adapt to a customer's behaviour and habits. This strengthens relationships among customers and companies. Unlike traditional marketing which focused on the company itself (the goal of targeting customers was to help the company sell as many products as possible at lower cost), CRM places the client in the center of its interests. Although the ultimate goal is still to increase the company profits, this is achieved by focusing on the customer service and taking their benefits and values into consideration, and not what the company wants to sell. This is achieved by strengthening the customer-company bond. CRM should not be seen as an overnight solution, but as a solution that contributes to organization profits in the long run. (Newell, 2002).

On this occasion we emphasize the fact that knowledge economy has changed the way of man's thinking, both as an individual and as a product buyer or service user, so the modern business practice must inevitably adapt to these changes. All participants in the knowledge economy, namely managers and their clients should take the following findings into consideration:

- Knowledge economy shifts from focusing on products and services themselves to focusing on the experience and knowledge of service / product users. This precisely is the area where companies find opportunities to differentiate and achieve competitive advantage.

- Companies, being aware of the need to transform its structures and processes, increasingly rely upon the knowledge they possess, not only about themselves, their employees, products and services, but also upon the knowledge of their service customers and product buyers.

- Knowledge economy alters the boundaries which define the main role protagonists in 
the economy: consumers are not only customers, but they enter the domain and authority of the seller by their involvement in product design innovation and service development; sellers are able to put themselves in the position of their costumers by adopting knowledge about their experiences, needs and aspirations. This relation, two-sided in all respects, brings benefits to both parties.

- Product buyers and service users access more easily to various information and knowledge related to the purchase and manufacturers, they adapt to e-commerce and online shopping, their taste and needs change often and rapidly, and their main producer directed requirement is an individual approach achieved by possessing knowledge about clients.

- Organizations know how much knowledge their employees have, and this knowledge should be multidimensional, competent, accessible and applicable.

The intention of the authors of this paper is to point out the necessity of innovative application and interrelating the modern management and marketing concepts in order to achieve and maintain competitive advantage of organizations. We put special emphasis on understanding the advantages offered by the concept of CKM. In this sense, the application of this concept provides answers to the following important issues:

- An effective response to the expressed demands for quality servicing of consumer and customer needs and demands;

- Creating products and services that will serve to meet new needs and requirements customers are often not aware of;

- Adequate response to requests for the products and services which will facilitate and simplify clients' life and work;

- Finding a solution to the issue of the lack of time, especially the time spent on browsing product ranges and shopping; and

- Customer impatience in terms of time and the speed of a company's feedback to their needs and requirements.

We believe that the benefits of the aforementioned concept can be the key to achieving and maintaining competitive advantage of organizations in an environment of multidimensional problemsolving as an imperative of modern business.

\section{REFRENCES}

Bitner, M.J., Booms, B.H., Tetreault, M.S. (1990) The service encounter: diagnosing favorable and unfavorable incidents. Journal of Marketing, 54 (1), 71-84.

Dobrijević, G. (2010) Rastući značaj interne komunikacije za poslovni uspeh kompanija. Singidunum revija, 5 (1), 1-9. (in Serbian)

Dous, M., Kolbe, L., Salomann, H., Brenner, W. (2005) Knowledge Management Capabilities in CRM: Making Knowledge For, From and About Customers Work. $11^{\text {th }}$ American Conference on Information Systems, 1114 August 2005 Omaha. [online] Available from: www. alexandria.unisg.ch/export/DL/28246.pdf, [accessed on 8 February 2011].

Draker, P., (2002) Upravljanje u novom društvu. Novi Sad: Adižes. (in Serbian)

Đorđević-Boljanović, J. (2009) Menadžment znanja, Belgrade: Data Status. (in Serbian)

Egan, J. (2004) Relationship Marketing. Essex: Pearson Education Limited.

Gibbert M., Leibold, M., Probst, G. (2002) Five Styles of Customer Knowledge Management, and How Smart Companies Use Them To Create Value. European Management Journal. 20 (5), 459-469.

Glazer, R., (2004) Role of smart markets in managing relationships with customers. In: Peppers, D., Rogers ,M., Managing Customer Relationships. New Jersey: John Wiley \& Sons, Inc.

Gordon, I.H. (1998) Relationship Marketing. Ontario: John Wiley \& Sons.

Gummesson, E. (1999) Total Relationship Marketing: Rethinking Marketing Management from 4Ps to 30Rs. Oxford: Butterworth Heinemann.

Håkansson, H., Johanson, J. (2001) Business network learning: basic considerations. In: Håkansson, H., Johanson, J., eds, Business Network Learning. Amsterdam: Elsevier Science.

Knox, S., Maklan, S., Payne, A., Peppard, J., Ryals, L. (2003) Customer Relationship Management. Oxford: Butterworth-Heinemann.

Kotler, P. (2003) Marketing Management. New Jersey: Pearson Education, Inc.

Macintosh, A. (1995) Position Paper on Knowledge Management. Artifical Intelligence Applications Institute, Edinburgh: University of Edinburgh.

MacStravic, S. (2004) Knowledge Management and CRM. Inside Knowledge Magazine. [online] Available from: www.ikmagazine.com [accessed on 10 February 2011]. 
Malhotra, Y. (1997) Knowledge Management in Inquiring Organizations. Proceeding of the 3rd Americas Conference on Information System (Philosophy or Information Systems - in Track), 15-17 August 1997 Indianapolis.

McNamara, S. (2011) Consumer Involvement Theory. [online] Available from: http://www.adcracker.com/ involvement/Consumer_Involvement_Theory.htm [accessed on 26 September 2011].

Mertins, K., Heising, P., Vorbeck, J. (2001) Knowledge Management. Best Practice in Europe. Amsterdam: Springer.

Newell, F. (2002) Loyality.com: Customer Relationship Management in the New Era of Internet Marketing. New Delhi: McGraw Hill.

Nikolić, M., Terek, E. (2011) The analysis of the current state of organizational culture and public relations in Serbian companies. Singidunum Revija. 8 (1), 207-215.

Parvatiyar, A., Sheth, J. (2001) Conceptual framework of customer relationship management. In: Sheth, J., Parvatiyar, A., Shainesh, G., eds. Customer Relationship Management-Emerging Concepts, Tools and Applications. New Delhi: McGraw-Hill.

Payne, A. (2006) Handbook of CRM: Achieving Excellence in Customer Management. Oxford: ButterworthHeinemann.

Peppers, D., Rogers, M. (2000) Build a One-to-One Learning Relationship with Your Customers. Interactive Marketing. 1 (3), 243-250.
Peppers, D., Rogers, M. (2004) Managing Customer Relationships. New Jersey: John Wiley \& Sons, Inc.

Pine, B.J., Peppers, D., Rogers, M. (1995) Do You Want to Keep Your Customers Forever? Harvard Business Review, March-April, 103-114.

Santosus, M., Surmacz, J. (2011) ABC of Knowledge Management. [online] Available from: www.cio.com/research/knowledge/edit/kmabc.html [accessed on 4 January 2011].

Selnes, F., Sallis, J. (2003) Promoting relationship learning, Journal of Marketing. 67 (3) 80-95.

Stanković J. (2009) Upravljanje promenama u odnosima sa potrošačima u maloprodajnom poslovanju. Thesis, $\mathrm{PhD}$. Faculty of Economy, University of Belgrade. (in Serbian)

Tiwana A. (2001) Essential Guide to Knowledge Management, The: E-Business and CRM Aplications. New York: Prentice Hall.

Varki S., Wong S. (2003) Consumer Involvement in Relationship Marketing of Services. Journal of Service Research. 6 (1), 83-91.

West, P. (2000) What Makes a Successful Retailer? Retail Strategy International. London: Sterling Publications Ltd.

\section{ULOGA MENADŽMENTA ZNANJA U IZGRADNJI ODNOSA SA KLIJENTIMA}

\section{Rezime:}

Menažment znanja predstavlja interdisciplinarni poslovni model, u čijem se fokusu nalazi generisanje i razmena znanja unutar organizacije. U procesima generisanja i distribucije znanja, ključnu ulogu imaju zaposleni, čije zadovoljstvo čini paradigmu ostvarivanja uspešnog menadžmenta znanja.

Tokom protekle decenije, menadžment odnosa sa klijentima pokazao se kao koncept neophodan za ostvarivanje poslovnog uspeha u praksi preduzeća na svetskom tržištu. Njegova suština zasniva se na uspostavljanju i održavanju dugoročnih odnosa sa klijentima, sa ciljem stvaranja vrednosti kako za klijenta, tako za organizaciju. Kao i svaka druga vrsta odnosa, i odnosi koje organizacija gradi sa svojim klijentima doživljavaju promene tokom tzv. „životnog ciklusa odnosa sa klijentima“. Tokom ovog procesa, stvaraju se "prinosi na poslovne odnose“ čiji je preduslov upravo smešten unutar same organizacije.

Direktno upućeni ka istom cilju, a to je satisfakcija potrošača, koncepti CRM i menadžment znanja, u svojoj sinergetskoj formi, deluju putem integrisanog koncepta Menadžmenta znanja o potrošačima, odnosno klijentima preduzeća. Multidimenzionalnost savremenog poslovanja zahteva povezivanje kompetencija stručnjaka bazičnih poslovnih oblasti, među kojima poseban akcenat treba staviti na deljenje znanja, komunikaciju i građenje partnerskih odnosa u poslovanju.

\section{Ključne reči:}

menadžment odnosa sa klijentima, partnerski odnosi, životni ciklus odnosa sa klijentima, povezivanje kompetencija.

Received: January 16th, 2012

Correction: February 4th, 2012

Accepted: February 17th, 2012 